\title{
Clinicopathologic and Molecular Analysis of Inflammatory Pseudotumor-Like Follicular/Fibroblastic Dendritic Cell Sarcoma: A Case Report and Review of Literature
}

\author{
Bryan MORALES-VARGAS $\mathbb{D}$, Kristin DEEB $\mathbb{D}$, Deniz PEKER
}

Department of Pathology and Laboratory Medicine, Emory University School of Medicine, GEORGIA, USA

\begin{abstract}
Inflammatory pseudotumor-like follicular/fibroblastic dendritic cell (FDC/FRC) sarcoma is an extremely rare neoplasm of the spleen associated with EBV and characterized by spindle cell morphology, dense mixed chronic inflammatory background, and a broad immunophenotypic profile often causing a diagnostic challenge for pathologists. The molecular features of FDC/FRC sarcoma are largely unknown due to a lack of comprehensive data. Here we present the results of next-generation sequencing and Single Nucleotide Polymorphism Copy Number array analysis in a case of FDC/FRC and review the literature.
\end{abstract}

Keywords: Inflammatory pseudotumor-like follicular/fibroblastic dendritic cell sarcoma, Splenic tumor, BCOR1L1, JAK2

\section{INTRODUCTION}

Inflammatory pseudotumor-like follicular/fibroblastic dendritic cell (FDC/FRC) sarcoma, a subgroup of follicular dendritic cell sarcoma (FDC), is rare neoplasm that often occurs in the spleen (1-15). FDC/FRC sarcoma can involve other anatomical sites including the liver (13, 16-23), colon $(24,25)$, and peripancreas $(17,20)$. The tumor has a predilection for young to middle-age adults and may present with various symptoms including fever, abdominal pain, sweats, fatigue (predominantly in women), and more often splenic solitary lesions $(5,6,9)$. FDC/FRC sarcoma is a lesion of neoplastic spindled cells with often follicular dendritic cell differentiation and over $90 \%$ of the cases are associated with EBV infection (9). Here, we discuss the clinicopathologic and molecular features of a localized splenic FDC/FRC sarcoma in an older age female and review the English-language literature.

\section{CASE REPORT}

A 66-year-old female patient presented with a two-month history of left upper quadrant pain. She had no relevant clinical history and denied systemic symptoms including fever, weight loss, and night sweats. Physical exam was overall unremarkable. Imaging studies revealed a welldefined splenic nodule measuring $4.5 \mathrm{~cm}$ on ultrasound and $5.0 \mathrm{~cm}$ on computerized tomography (CT), which was not present on a prior CT performed in 2017. There were no suspicious lymph node enlargement, hepatomegaly, or

(Turk Patoloji Derg 2021, 37:266-272)

Received : 10.11.2020 Accepted : 24.12.2020 other organ abnormalities on abdominal computerized tomography. She underwent elective splenectomy.

Histomorphologic, Immunophenotypic, and Molecular Analysis

Macroscopic examination revealed a $130 \mathrm{mg}$ spleen containing a well-circumscribed, moderately firm, red-pink mass. The hematoxylin and eosin sections demonstrated splenic parenchyma with a lesion that resembled splenic parenchyma with white and red pulp structures without overt morphologic atypia (Figure 1A). Also noted were somewhat spindled histiocytoid cell clusters that had a moderate amount of pale cytoplasm, oval vesicular nuclei, inconspicuous nucleoli, delicate fibrous bands, and increased vascularity (Figure 1B). In addition, there was a polymorphous proliferation of plasma cells and small lymphocytes admixed in the background. Ancillary immunohistochemical studies were performed on formalinfixed, paraffin-embedded (FFPE) tissue sections following routine procedures for $\mathrm{CD} 20, \mathrm{CD} 3, \mathrm{CD} 5$, smooth muscle actin (SMA), CD20, CD21, CD23, CD68, BLC6, IgG, IgG4, PAX-5 AE1/AE3, and Ki-67. Epstein Barr virus encoded small RNAs (EBER) in situ hybridization was performed with immunohistochemistry/EBER (please see Table I for additional antibody information). CD3, CD5, and CD43 were expressed in the background $\mathrm{T}$-cell population while CD20 and PAX-5 highlighted the B-cells forming follicles in the white pulp with partial BCL6 expression.

Correspondence: Bryan MORALES-VARGAS

Emory University School of Medicine, Pathology and Laboratory Medicine, GEORGIA, USA

E-mail: bryan.morales@emory.edu Phone: : +1 4047123855 
Atypical spindled cells were positive for CD35 (Figure 1C), CD23 (Figure 1D), and CD21 (partial) as well as SMA (Figure 1E), consistent with a follicular dendritic cell and myofibroblastic origin, respectively. EBV-encoded small RNA was extensively positive using in situ hybridization (EBER) (Figure 1F).

Single Nucleotide Polymorphism Copy Number (SNP-CN) array analysis using the Thermo Fisher OncoScan FFPE Assay Kit (Thermo Fisher Scientific, Waltham, MA) was performed according to the manufacturer's directions and revealed a copy neutral loss of heterozygosity of $5 \mathrm{q}$ in $100 \%$ of the specimens, which was considered constitutional. Also detected was a gain of the $\mathrm{X}$ chromosome that was clonal and the clinical significance of this finding was unclear (Figure 2A-B). To better characterize this tumor, somatic mutation detection by next-generation sequencing was performed (Myeloid 75-gene targeted sequencing panel). Two variants were detected by the Archer ${ }^{\oplus}$ VariantPlex Myeloid 75-gene panel BCORL1 c.3463C $>$ A (p.P1155T) in approximately $56 \%$ of the alleles and JAK2 c.2852T $>C$ (p.I951T) in approximately $47 \%$ of the alleles. These two variants are observed as germline variants in a minor proportion of the population with BCORL1 seen in 6 alleles and JAK2 seen in 10 alleles (both with minor allele frequencies of approximately $\left.3.6 \times 10^{-5}\right)(26)$. In silico algorithms predict the variants to be tolerated/benign (provean.jcvi.org). Therefore, given the information currently available, the clinical significance of these variants is uncertain at best. Polymerase chain reaction did not detect rearrangement of the T-cell receptor or $\mathrm{IgH}$.

A diagnosis of inflammatory pseudotumor-like follicular/ fibroblastic dendritic cell tumor (FDC/FRC) was rendered. The patient was followed up for 6 months after the surgery and no recurrent disease was identified. She remains in remission to our knowledge.
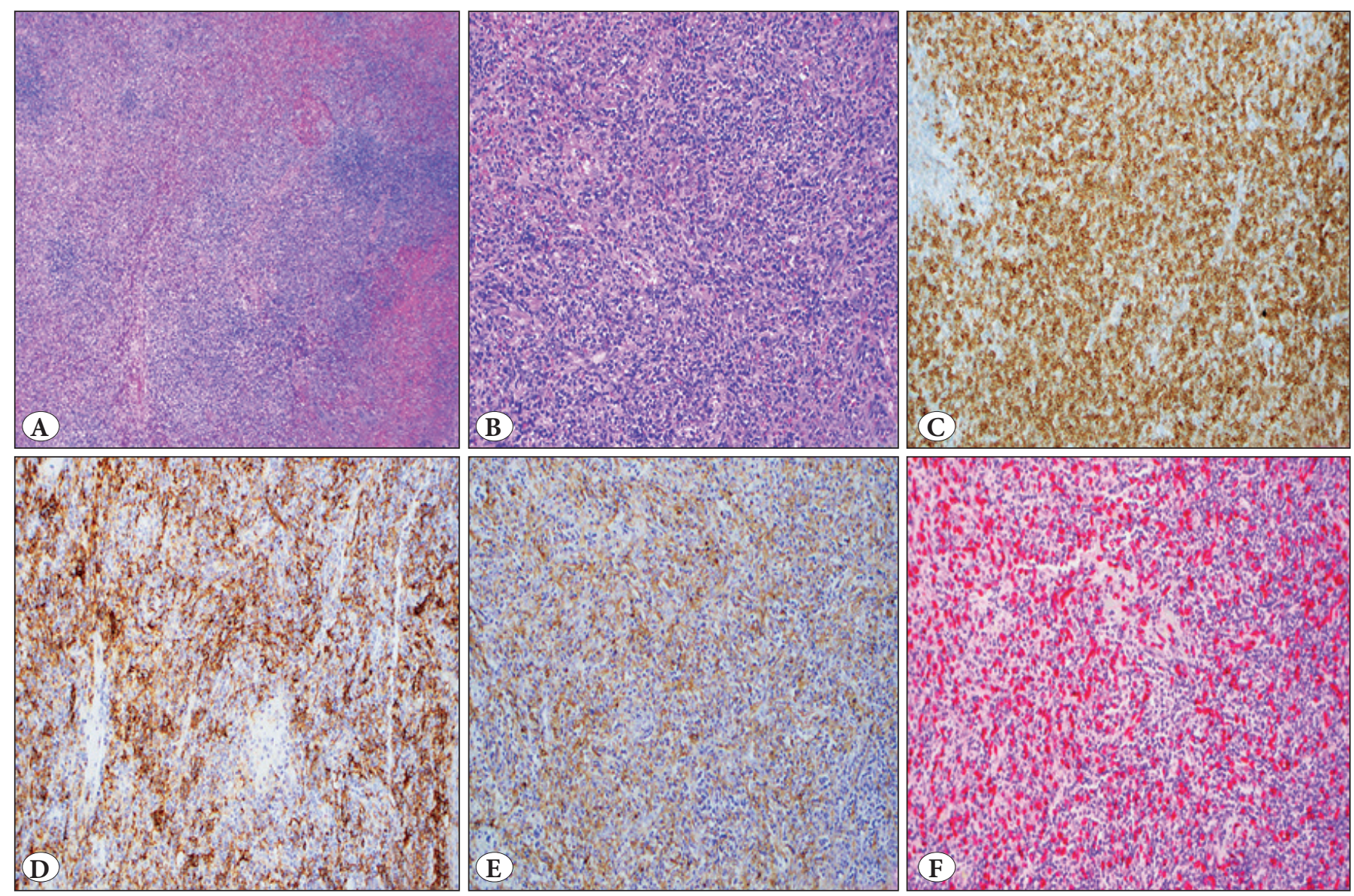

Figure 1: A) Splenic parenchyma with partially altered architecture (H\&E; x20) B) by the spindled cells in the background of chronic inflammatory cells (H\&E; x200). The spindled cells show expression of C) CD35 (IHC; x200), D) CD23 (IHC; x200), E) SMA (IHC; x200), with numerous cells positive for F) EBER (ISH; x200). 


\section{DISCUSSION}

FDC/FRC is a rare subtype of FDCS with a favorable clinical course, and surgical treatment alone is often the therapeutic approach. A slight female predilection was observed with a male to female ratio of 0.6 . The tumor affects mostly the adult population with the age varying between 19 and 79 years. One third of the patients were asymptomatic $(n=21)$ while the remaining patients presented with various symptoms including abdominal pain, and gastrointestinal and other systemic symptoms. EBV positivity in tumor cells was consistently present. At least one FDC marker was positive in nearly all patients except for one case (15), and SMA was expressed in the majority of the cases.
The histomorphologic and immunophenotypic features of FDC/FRC resemble other spindled cell tumors that are more aggressive and potentially require more aggressive treatments. Therefore, it is crucial to perform a thorough diagnostic work-up to render an accurate diagnosis. FDC/ FRC sarcoma harbors mesenchymal and inflammatory components and a wide range of immunophenotypic profiles causing a diagnostic challenge in differentiating it from other spindle cell tumors of the spleen including follicular dendritic cell sarcoma, interdigitating dendritic cell sarcoma arising in or involving the spleen, fibroblastic reticular cell tumor, and reactive processes such as splenic inflammatory pseudotumor also known as inflammatory

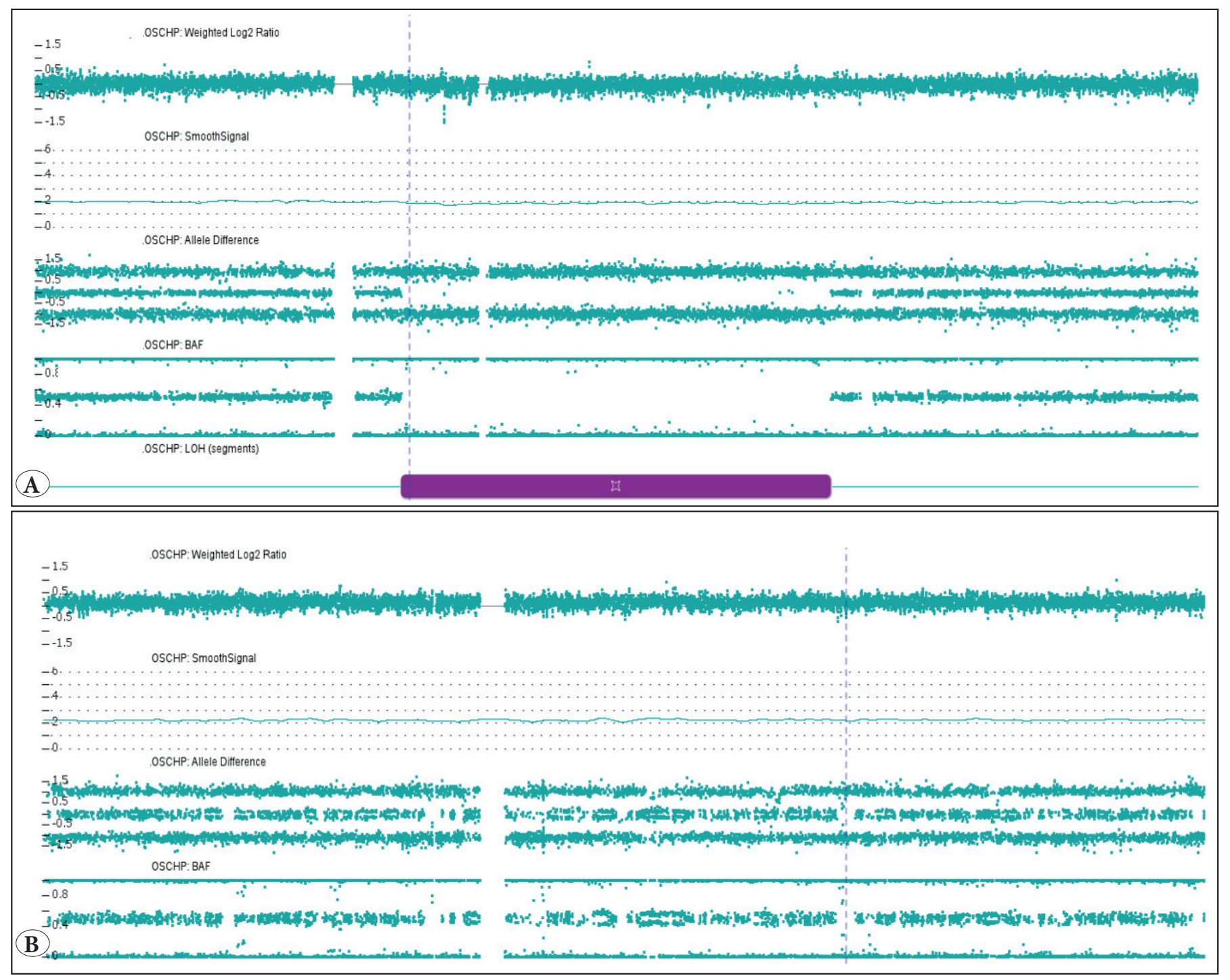

Figure 2: SNP-CN array analysis of chromosome 5 and chromosome X. A) Approximately 66.8-Mb (megabase) stretch of copy neutral loss of heterozygosity $(\mathrm{CN}-\mathrm{LOH})$ was detected interstitially on the long arm of chromosome 5 . B) A clonal low-level loss of the entire X chromosome was detected in the splenic specimen. 
Table I: Antibodies used in this study

\begin{tabular}{lllll}
\hline Antigen & Clone & Dilution & Source & Platform used \\
\hline CD3 & LN10 & Ready-to-use & Leica Microsystems, Buffalo Groove, IL, USA & Bond Automated IHC Stainer \\
\hline CD5 & 4C7 & Ready-to-use & Leica Microsystems, Buffalo Groove, IL, USA & Bond Automated IHC Stainer \\
\hline CD20 & L26 & Ready-to-use & Leica Microsystems, Buffalo Groove, IL, USA & Bond Automated IHC Stainer \\
\hline CD21 & 2G9 & Ready-to-use & Leica Microsystems, Buffalo Groove, IL, USA & Bond Automated IHC Stainer \\
\hline CD23 & 1B12 & Ready-to-use & Leica Microsystems, Buffalo Groove, IL, USA & Bond Automated IHC Stainer \\
\hline BCL6 & KP1 & x 3200 & Dako Cytomation, Carpinteria, CA, USA & Bond Automated IHC Stainer \\
\hline IgG & & Ready-to-use & Leica Microsystems, Buffalo Groove, IL, USA & Bond Automated IHC Stainer \\
\hline IgG4 & HP6025 & x 8,000 80,000 & Dako Cytomation, Carpinteria, CA, USA & Bond Automated IHC Stainer \\
\hline EBER & Leica Probe & Ready-to-use & Leica Microsystems, Buffalo Groove, IL, USA & Bond Automated IHC Stainer \\
\hline PAX-5 & 24 & x 2 & Cell Marque, Rocklin, CA, USA & Bond Automated IHC Stainer \\
\hline $\begin{array}{l}\text { Smooth } \\
\text { muscle actin }\end{array}$ & 1A4 & x 1600 & Dako Cytomation, Carpinteria, CA, USA & Bond Automated IHC Stainer \\
\hline Ki-67 & MIB-1 & x 80 & Dako Cytomation, Carpinteria, CA, USA & Bond Automated IHC Stainer \\
\hline AE1/AE3 & AE1/AE3 & x 200 & Dako Cytomation, Carpinteria, CA, USA & Bond Automated IHC Stainer \\
\hline
\end{tabular}

myofibroblastic tumor (Table II). Ge et al. have authored a review manuscript and described the histomorphologic characteristics of FDC/FRC sarcoma in detail, including proliferation of neoplastic spindled cells with varying degree of nuclear atypia, a vesicular chromatin pattern, and conspicuous nucleoli in a background of lymphoplasmacytic infiltrate that may be accompanied by eosinophils, a granulomatous reaction, necrosis, and hemorrhage (9). The neoplastic cells are often of follicular dendritic cell origin with expression of CD21, CD23, or CD35, similar to follicular dendritic cell sarcoma (FDCS). However, although the spindled cell morphology and expression of dendritic cell markers are often shared by these two tumors, there are several differences: FDC/FRC sarcoma is often an isolated lesion and almost exclusively associated with EBV. FDC may occur in multiple sites and, in addition to FDC markers, Clusterin, a glycoprotein associated with apoptosis, is frequently expressed in FDCS (27), although not reported in FDC/FRC sarcoma. On the other hand, fibroblastic reticular cell differentiation and SMA expression are not commonly observed in FDCS (28). The differentiation between FDC/FRC sarcoma and FDCs is crucial given the biological behavior of inflammatory FDC/FRC sarcoma is more indolent than a true intraabdominal FDC. Interdigitating dendritic cell sarcoma (IDCS) is another dendritic cell tumor characterized by neoplastic proliferation of spindled to ovoid cells arranged in fascicles or whorls or in a storiform pattern (1). Tumor cells are consistently positive with $\mathrm{S} 100$ and Vimentin, which are mostly negative in FDC/FRC sarcoma. IDCS has an aggressive clinical course in the majority of the cases. Fibroblastic reticular cell tumor (FRCT) is a rare neoplasm that can be seen in the spleen. FRCT has a similar histomorphology to other dendritic cell tumors with a rather distinct immunophenotype including expression of SMA, desmin, and CD68 as well as cytokeratin, which separates it from the others. Our case was also negative with AE1/AE3. Splenic inflammatory pseudotumor (IPT) is a rare benign reactive process resulting from an infectious, autoimmune or reparative process, with subsets expressing EBV (29). EBV+ IPT often has a similar histomorphology to FDC/ FRC sarcoma including isolated nodules formed by a bland spindled myofibroblastic proliferation and a polymorphic inflammatory infiltrate that can be accompanied by hemorrhage. The myofibroblasts are characteristically positive for SMA, Vimentin and, in subsets, CD68 without expression of FDC markers (30).

The molecular pathogenesis of the disease is poorly understood. Gain of chromosome X was detected by SNP array in our case and was considered clonal; however, the association of such an anomaly with FDC/FRC sarcoma has not been reported to our knowledge. Gain of the $\mathrm{X}$ chromosome in the current case may suggest chromosome X mosaicism, which is usually age-related 
Table II: Clinicopathologic and immunophenotypic features of spindled cell tumors of the spleen

\begin{tabular}{|c|c|c|c|c|c|}
\hline & Demographics & $\begin{array}{l}\text { Most common } \\
\text { localization }\end{array}$ & Histology & Immunophenotype & Prognosis \\
\hline FDC/FRC & $\begin{array}{l}\text { Adult/Female } \\
\text { predilection }\end{array}$ & $\begin{array}{l}\text { Spleen, liver, } \\
\text { gastrointestinal } \\
\text { tract }\end{array}$ & $\begin{array}{l}\text { Spindled cells, bland to } \\
\text { pleomorphic morphology, } \\
\text { dense background } \\
\text { lymphoplasmacytic } \\
\text { infiltrate, necrosis and } \\
\text { hemorrhage }\end{array}$ & $\begin{array}{l}\mathrm{CD} 21+, \mathrm{CD} 23+, \\
\mathrm{CD} 35+, \mathrm{SMA}+, \mathrm{EBV}+\end{array}$ & $\begin{array}{l}\text { Good prognosis, } \\
\text { local recurrence }\end{array}$ \\
\hline FDC & $\begin{array}{l}\text { Adult/ no sex } \\
\text { predilection }\end{array}$ & $\begin{array}{l}\text { Lymph } \\
\text { node, tonsil, } \\
\text { gastrointestinal } \\
\text { tact soft tissue }\end{array}$ & $\begin{array}{l}\text { Spindled to ovoid cells, } \\
\text { forming whorls, fascicles, } \\
\text { storiform arrays, often } \\
\text { bland cytology, less dense } \\
\text { lymphocytic infiltrate }\end{array}$ & $\begin{array}{l}\mathrm{CD} 21+, \mathrm{CD} 23+, \\
\mathrm{CD} 35+, \text { Fascin }+ \\
\text { Clusterin+, CD68+ }\end{array}$ & $\begin{array}{l}\text { Worse prognosis; } \\
\text { large size, cytologic } \\
\text { atypia, necrosis, } \\
\text { and increased } \\
\text { mitotic activity }\end{array}$ \\
\hline IDCS & $\begin{array}{l}\text { Adult/Male } \\
\text { predilection }\end{array}$ & $\begin{array}{l}\text { Lymph node, } \\
\text { skin, soft tissue }\end{array}$ & $\begin{array}{l}\text { Round to spindled } \\
\text { cells forming sheets } \\
\text { of fascicles, whorls or } \\
\text { arranged in storiform } \\
\text { pattern. Necrosis not } \\
\text { present. }\end{array}$ & $\begin{array}{l}\text { S100+, Vimentin+, } \\
\text { Fascin+. No FDC } \\
\text { marker expression }\end{array}$ & $\begin{array}{l}\text { Often aggressive } \\
\text { clinical course }\end{array}$ \\
\hline FRCT & $\begin{array}{l}\text { Adult/Male } \\
\text { predilection }\end{array}$ & $\begin{array}{l}\text { Lymph node, } \\
\text { spleen, soft } \\
\text { tissue }\end{array}$ & Similar to FDC & $\begin{array}{l}\text { SMA+, Desmin+, } \\
\text { Cytokeratin+, CD68+ }\end{array}$ & $\begin{array}{l}\text { Variable (limited } \\
\text { data) }\end{array}$ \\
\hline EBV+ IPT & $\begin{array}{l}\text { Adult/Female } \\
\text { predilection }\end{array}$ & Spleen & Similar to FDC & $\begin{array}{l}\text { SMA+, Vimentin, } \\
\text { CD68, EBV+. } \\
\text { No FDC marker } \\
\text { expression }\end{array}$ & Good prognosis \\
\hline
\end{tabular}

FDC/FRC: Inflammatory pseudotumor-like follicular/fibroblastic dendritic cell; FDC: Follicular dendritic cell sarcoma; IDCS: Interdigitating dendritic cell sarcoma; FRCT: Fibroblastic retocular cell tumor; EBV-positive IPT: EBV-positive inflammatory pseudotumor.

and preferentially affects the inactivated $\mathrm{X}$ chromosome (31). The existing data from cancer genomes indicate that the female $\mathrm{X}$ chromosome, particularly inactive $\mathrm{X}$, usually has a higher mutation burden of point mutations and that this is a frequent event in cancer (32). Bruehl et al. recently reported the results of comprehensive mutation analysis using NGS in two cases of FDC/FRC sarcoma and found no variants of strong or potential clinical significance (33). The results of NGS in the current case were similar; variants were detected in BCORL1 and $J A K 2$. However, the clinical significance of BCORL1 and $J A K 2$, if any, is uncertain given their presence in a very minor fraction of the population database. Furthermore, whether these germline variants have susceptibility or predispose to hematologic malignancies are unknown at this time. BCORL1 and JAK2 gene alterations have been demonstrated in various tumors including myeloid neoplasms. Additionally, BCORL1 has been shown in medulloblastoma, retinoblastoma, and uterine sarcoma $(34,35)$ and might potentially be a pathogenic gene in the development of FDC/FRC. Although these variants may represent heterozygous germline sequence variants, the clinical significance of these variants in the context of this case is undetermined at this time and larger scale case series and studies are warranted to better understand the biology and clinical implications of this rare disease.

\section{AUTHORSHIP CONTRIBUTIONS}

Concept: DP, Design: BMV, DP, Data collection or processing: BMV, KD, DP, Analysis or Interpretation: BMV, KD, DP, Literature search: BMV, DP, Writing: BMV, DP, Approval: DP. 


\section{REFERENCES}

1. Swerdlow SH, World Health Organization, International Agency for Research on Cancer. WHO classification of tumours of haematopoietic and lymphoid tissues. Revised 4th. ed. Lyon: International Agency for Research on Cancer; 2017. 585.

2. Deng $\mathrm{S}$, Gao J. Inflammatory pseudotumor-like follicular dendritic cell sarcoma: A rare presentation of a hepatic mass. Int J Clin Exp Pathol. 2019;12:3149-55.

3. Hassan M, Qureshi A, Mamoon N, Ali Z. Follicular dendritic cell sarcoma presenting as colonic intussusception. J Pak Med Assoc. 2017;67:1923-6.

4. Choe JY, Go H, Jeon YK, Yun JY, Kim YA, Kim HJ, Huh J, Lee, $\mathrm{H}$, Shin DH, Kim JE. Inflammatory pseudotumor-like follicular dendritic cell sarcoma of the spleen: A report of six cases with increased IgG4-positive plasma cells. Pathol Int. 2013;63:245-51.

5. Brittig F, Ajtay E, Jakso P, Kelenyi G. Follicular dendritic reticulum cell tumor mimicking inflammatory pseudotumor of the spleen. Pathol Oncol Res. 2004;10:57-60.

6. Horiguchi $H$, Matsui-Horiguchi $M$, Sakata $H$, Ichinose $M$, Yamamoto T, Fujiwara M, H. Oshe. Inflammatory pseudotumorlike follicular dendritic cell tumor of the spleen. Pathol Int. 2004;54:124-31.

7. Arber DA, Kamel OW, van de Rijn M, Davis RE, Medeiros LJ, Jaffe ES, Lawrence W. Frequent presence of the Epstein-Barr virus in inflammatory pseudotumor. Hum Pathol. 1995;26:10938.

8. Yoon SO, Ko H, Kim B-H, Kwon GY, Jeon YK, Kim CW. EpsteinBarr virus-associated inflammatory pseudotumor-like follicular dendritic cell tumor in the spleen of a patient with diffuse large B cell lymphoma: A case report and review of the literature. Korean J Pathol. 2007;41:198-202.

9. Ge R, Liu C, Yin X, Chen J, Zhou X, Huang C, Yu W, Shen X. Clinicopathologic characteristics of inflammatory pseudotumorlike follicular dendritic cell sarcoma. Int J Clin Exp Pathol. 2014;7:2421-9.

10. Vardas K, Manganas D, Papadimitriou G, Kalatzis V, Kyriakopoulos G, Chantziara M, Exarhos D, Drakopoulos S. Splenic inflammatory pseudotumor-like follicular dendritic cell tumor. Case Rep Oncol. 2014;7:410-6.

11. Kitamura Y, Takayama Y, Nishie A, Asayama Y, Ushijima Y, Fujita N, Morita K, Baba S, Kubo Y, Shirabe K, Honda H. Inflammatory pseudotumor-like follicular dendritic cell tumor of the spleen: Case report and review of the literature. Magn Reson Med Sci. 2015;14:347-54.

12. Bui PL, Vicens RA, Westin JR, Jensen CT. Multimodality imaging of Epstein-Barr virus-associated inflammatory pseudotumorlike follicular dendritic cell tumor of the spleen: case report and literature review. Clin Imaging. 2015;39:525-8.

13. Chen Y, Shi H, Li H, Zhen T, Han A. Clinicopathological features of inflammatory pseudotumour-like follicular dendritic cell tumour of the abdomen. Histopathology. 2016;68:858-65.

14. Hang JF, Wang LC, Lai CR. Cytological features of inflammatory pseudotumor-like follicular dendritic cell sarcoma of spleen: A case report. Diagn Cytopathol. 2017;45:230-4.
15. Rosenbaum L, Fekrazad MH, Rabinowitz I, Vasef MA. EpsteinBarr virus-associated inflammatory pseudotumor of the spleen: Report of two cases and review of the literature. J Hematop. 2009;2:127-31.

16. Selves J, Meggetto F, Brousset P, Voigt JJ, Pradere B, Grasset D, Icart J, Mariamé B, Knecht H, Delsol G. Inflammatory pseudotumor of the liver. Evidence for follicular dendritic reticulum cell proliferation associated with clonal Epstein-Barr virus. Am J Surg Pathol. 1996;20:747-53.

17. Cheuk W, Chan JK, Shek TW, Chang JH, Tsou MH, Yuen NW, Ng W F, Chan A C, Prat J. Inflammatory pseudotumor-like follicular dendritic cell tumor: A distinctive low-grade malignant intra-abdominal neoplasm with consistent Epstein-Barr virus association. Am J Surg Pathol. 2001;25:721-31.

18. Bai LY, Kwang WK, Chiang IP, Chen PM. Follicular dendritic cell tumor of the liver associated with Epstein-Barr virus. Jpn J Clin Oncol. 2006;36:249-53.

19. Shek TW, Ho FC, Ng IO, Chan AC, Ma L, Srivastava G. Follicular dendritic cell tumor of the liver. Evidence for an Epstein-Barr virus-related clonal proliferation of follicular dendritic cells. Am J Surg Pathol. 1996;20:313-24.

20. Shek TW, Liu CL, Peh WC, Fan ST, Ng IO. Intra-abdominal follicular dendritic cell tumour: A rare tumour in need of recognition. Histopathology. 1998;33:465-70.

21. Chen TC, Kuo TT, Ng KF. Follicular dendritic cell tumor of the liver: A clinicopathologic and Epstein-Barr virus study of two cases. Mod Pathol. 2001;14:354-60.

22. Granados R, Aramburu JA, Rodriguez JM, Nieto MA. Cytopathology of a primary follicular dendritic cell sarcoma of the liver of the inflammatory pseudotumor-like type. Diagn Cytopathol. 2008;36:42-6.

23. Liu Y, Li L, Hu Q, Miranda RN. Inflammatory pseudotumorlike follicular dendritic cell tumor of the liver with expression of estrogen receptor suggests a pathogenic mechanism: A case report and review of the literature. Journal of Hematopathology. 2010;3(2):109-15.

24. Ke X, He H, Zhang Q, Yuan J, Ao Q. Epstein-Barr virus-positive inflammatory follicular dendritic cell sarcoma presenting as a solitary colonic mass: Two rare cases and a literature review. Histopathology. 2020;77:832-40.

25. Pan ST, Cheng CY, Lee NS, Liang PI, Chuang SS. Follicular dendritic cell sarcoma of the inflammatory pseudotumorlike variant presenting as a colonic polyp. Korean J Pathol. 2014;48:140-5.

26. Karczewski KJ, Francioli LC, Tiao G, Cummings BB, Alföldi J, Wang Q, Collins RL, Laricchia KM, Ganna A, Birnbaum DP, Gauthier LD, Brand H, Solomonson M, Watts NA, Rhodes D, Singer-Berk M, England EM, Seaby EG, Kosmicki JA, Walters RK, Tashman K, Farjoun Y, Banks E, Poterba T, Wang A, Seed C, Whiffin N, Chong JX, Samocha KE, Pierce-Hoffman E, Zappala Z, O’Donnell-Luria AH, Minikel EV, Weisburd B, Lek M, Ware JS, Vittal C, Armean IM, Bergelson L, Cibulskis K, Connolly KM, Covarrubias M, Donnelly S, et al; Genome Aggregation Database Consortium, Neale BM, Daly MJ, MacArthur DG. The mutational constraint spectrum quantified from variation in 141,456 humans. Nature. 2020;581(7809):434-43. 
27. Dalia S, Shao H, Sagatys E, Cualing H, Sokol L. Dendritic cell and histiocytic neoplasms: Biology, diagnosis, and treatment. Cancer Control. 2014;21:290-300.

28. Majhi U, Shirley S, Murhekar K. Follicular dendritic cell sarcoma of oral cavity: Report of 2 cases. Indian J Pathol Microbiol. 2007;50:545-7.

29. Van Baeten C, Van Dorpe J. Splenic Epstein-Barr VirusAssociated Inflammatory Pseudotumor. Arch Pathol Lab Med. 2017;141:722-7.

30. Kalaivani V, Vijayakumar HM, Girish KS, Hegde N. Inflammatory pseudotumour of the spleen: A diagnostic dilemma. J Clin Diagn Res. 2013;7:1460-2.

31. Machiela MJ, Zhou W, Karlins E, Sampson JN, Freedman ND, Yang Q, Hicks B, Dagnall C, Hautman C, Jacobs KB, Abnet CC, Aldrich MC, Amos C, Amundadottir LT, Arslan AA, BeaneFreeman LE, Berndt SI, Black A, Blot WJ, Bock CH, Bracci PM, Brinton LA, Bueno-de-Mesquita HB, Burdett L, Buring JE, Butler MA, Canzian F, Carreón T, Chaffee KG, Chang IS, Chatterjee N, Chen C, Chen C, Chen K, Chung CC, Cook LS, Crous Bou M, Cullen M, Davis FG, De Vivo I, Ding T, Doherty J, Duell EJ, Epstein CG, Fan JH, et al. Female chromosome X mosaicism is age-related and preferentially affects the inactivated X chromosome. Nat Commun. 2016;7:11843.
32. Jäger $N$, Schlesner $M$, Jones DT, Raffel S, Mallm JP, Junge KM, Weichenhan D, Bauer T, Ishaque N, Kool M, Northcott PA, Korshunov A, Drews RM, Koster J, Versteeg R, Richter J, Hummel M, Mack SC, Taylor MD, Witt H, Swartman B, SchulteBockholt D, Sultan M, Yaspo ML, Lehrach H, Hutter B, Brors B, Wolf S, Plass C, Siebert R, Trumpp A, Rippe K, Lehmann I, Lichter P, Pfister SM, Eils R. Hypermutation of the inactive X chromosome is a frequent event in cancer. Cell. 2013;155:567-81.

33. Bruehl FK, Azzato E, Durkin L, Farkas DH, Hsi ED, Ondrejka SL. Inflammatory pseudotumor-like follicular/fibroblastic dendritic cell sarcomas of the spleen are EBV-associated and lack other commonly identifiable molecular alterations. Int J Surg Pathol. 2020:1066896920949675.

34. Yamamoto Y, Abe A, Emi N. Clarifying the impact of polycomb complex component disruption in human cancers. Mol Cancer Res. 2014;12:479-84.

35. Yoshida A, Arai Y, Hama N, Chikuta H, Bando Y, Nakano S, Kobayashi E, Shibahara J, Fukuhara H, Komiyama M, Watanabe SI, Tamura K, Kawai A, Shibata T. Expanding the clinicopathologic and molecular spectrum of BCOR-associated sarcomas in adults. Histopathology. 2020;76:509-20. 